\title{
Copyright for Literate Robots
}

\author{
James Grimmelmann*
}

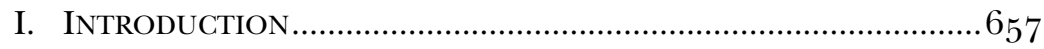

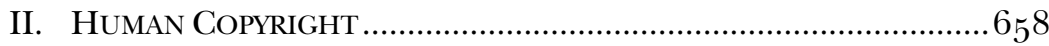

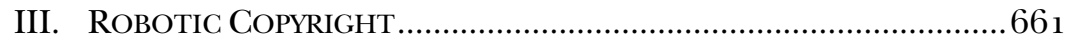

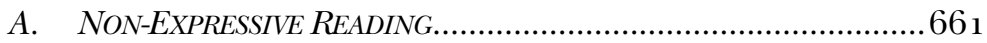

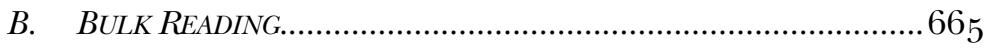

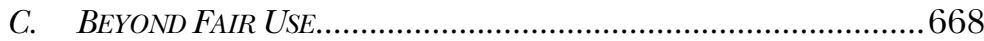

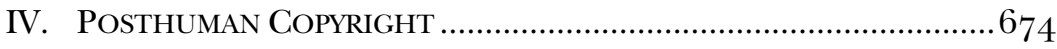

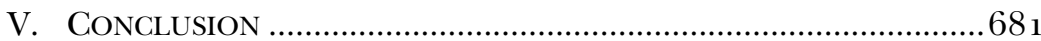

\section{INTRODUCTION}

Almost by accident, copyright law has concluded that it is for humans only: reading performed by computers doesn't count as infringement. Conceptually, this makes sense: Copyright's ideal of romantic readership involves humans writing for other humans. But in an age when more and more manipulation of copyrighted works is carried out by automated processes, this split between human reading (infringement) and robotic reading (exempt) has odd consequences: it pulls us toward a copyright system in which humans occupy a surprisingly peripheral place. This Article describes the shifts in fair use law that brought us here and reflects on the role of robots in copyright's cosmology.

* Professor of Law, University of Maryland Francis King Carey School of Law. My thanks to Aislinn Black, Annemarie Bridy, Jake Linford, Fred von Lohmann, Tom Rubin, Matthew Sag, Evan Selinger, and the participants in the 2015 Works in Progress Intellectual Property Colloquium for their suggestions. After January 1, 2016, this Article is available for reuse under the Creative Commons Attribution 4.o International license, https://creativecommons.org/ licenses/by/4.o. 


\section{HUMAN COPYRIGHT}

Quietly, invisibly almost by accident, copyright has concluded that reading by robots doesn't count. Infringement is for humans only; when computers do it, it's fair use. This is an article about how it happened and some of the implications.

To understand robotic readership, we should start by talking about human authorship, ${ }^{1}$ or more specifically, the ideal of "romantic" authorship. ${ }^{2}$ The name is not to suggest that there is something swoon-inducing about picking up a pen, but rather that the sort of creativity copyright concerns itself with is the product of a specific human mind. To quote a famous passage from Justice Holmes, "The copy is the personal reaction of an individual upon nature. Personality always contains something unique. It expresses its singularity even in handwriting, and a very modest grade of art has in it something irreducible, which is one man's alone. That something he may copyright ....."3

Human readership, on this view, is engagement with an author's expression. Copyright insists, for example, that substantial similarity for infringement purposes is a matter of readers' perceptions of works, rather than inhering in the works themselves. 4 To quote an equally famous passage from Judge Learned Hand, a defendant's work infringes on the plaintiff's if "the ordinary observer, unless he set out to detect the disparities, would be disposed to overlook them, and regard their aesthetic appeal as the same." 5 In an important sense, copyright embraces an ideal of romantic readership that is the dual of romantic authorship. What readers are deemed to care about in a work of authorship as a copyrightable work-what makes it valuable

1. I will use "reading" generically to refer to the whole range of ways in which one can experience a work: reading, listening, watching, glancing, observing from all angles, and so on. For reasons that will become clear, textual works are at the heart of the transformation this Article traces. I will also use "robot" to refer to computer programs as well as mechanical devices; that usage fight has already been lost.

2. See, e.g., Mark Rose, Authors And Owners: The Invention of Copyright (1993) (discussing the rise of authorship and literary property in England); James Boyle, A Theory of Law and Information: Copyright, Spleens, Blackmail, and Insider Trading, 8o CALIF. L. REv. 14113, $1467-70$ (1992) (discussing the role of "originality" in American copyright law); Peter Jaszi, Toward a Theory of Copyright: The Metamorphoses of "Authorship," 1991 DUKE L.J. 455 (discussing use of concept in contemporary copyright law); Martha Woodmansee, The Genius and the Copyright: Economic and Legal Conditions of the Emergence of the "Author," 17 EIGHTEENTH-CENTURY STUD. 425 (1984) (tracing the historical emergence of the romantic author ideal in Germany).

3. Bleistein v. Donaldson Lithographing Co., 188 U.S. 239, $25^{\circ}$ (1903).

4. See Swirsky v. Carey, 376 F.3d 841, 845 (9th Cir. 2004) (explaining that "subjective intrinsic test" of similarity "must be left to the jury"); Jeanne C. Fromer \& Mark A. Lemley, The A udience in Intellectual Property Infringement, 112 MICH. L. REV. 1251, 1267-73 (2014).

5. Peter Pan Fabrics, Inc. v. Martin Weiner Corp., 274 F.2d 487, 489 (2d Cir. 196o). 
to them as copyright's ideal readers-is the author's originality. ${ }^{6}$ Hand's "aesthetic appeal" to readers is Holmes's author's "personal reaction of an individual upon nature." 7 This is why similarities to the unoriginal portions of a plaintiff's work cannot support an infringement action, even if they are what make the work distinctive or drive its sales. ${ }^{8}$ Copyright's romantic readers are drawn to a work because something of the author's unique humanity (as expressed in the work) resonates with their own.

In a world of books and other pre-digital technologies, "copyright . . . left reading, listening, and viewing unconstrained." 9 Ordinary acts of reading did not result in any new copies, and hence did not trigger any of the copyright owner's exclusive rights; nor did readers have access to technologies that would have made copying easy. ${ }^{10}$ The boundary between authors and readers was clear and simple: Authors made copies regulated by the copyright system, while readers did not make copies and existed outside its formal bounds. Modern media technologies from the VCR onwards have made reader copying much easier, and digital media technologies often make copies as part of the ordinary reading or playback process. ${ }^{11}$ The result is that readers now regularly attract copyright's attention; fair use has stepped in to ensure that ordinary acts of reading remain noninfringing. ${ }^{12}$

Now for the third participant in copyright's eternal triangle. "One who has slavishly or mechanically copied from others may not claim to be an author." ${ }_{13}$ We have another name for a "slavish copyist": an infringer. Authors create; readers read; copyists infringe. But this is not quite all, because the line between infringer and author is contestable. It is one thing to say that a pirate printer reaps where she has not sown, but what about the writer of a critical review? She is both a copyist and a creator. Whenever copyright can recognize in a copyist the same attributes it admires in authors, it resolves this

6. See Arnstein v. Porter, ${ }_{54}$ F.2d 464, 473 (2d Cir. 1946) (phrasing the infringement test as "whether defendant took from plaintiff's works ... what is pleasing to the ears of lay listeners, who comprise the audience for whom such popular music is composed").

7. See Bleistein, 188 U.S. at 25 o.

8. See, e.g., Kohus v. Mariol, 328 F.3d 848,855 (6th Cir. 2003) (stating that a court in an infringement case must "filter out the unoriginal, unprotectible [sic] elements" of the plaintiff's works before assessing similarity).

9. Jessica Litman, Lawful Personal Use, 85 TEX. L. REV. 1871,1882 (2007).

10. See 17 U.S.C. \$ 106 (2012) (listing exclusive rights, with "reading" conspicuously absent).

11. See generally Aaron Perzanowski, Fixing RAM Copies, 104 Nw. U. L. REv. 1067 (2010).

12. See Litman, supra note 9, at 1897-9o3; Aaron Perzanowski \& Jason Schultz, Copyright Exhaustion and the Personal Use Dilemma, 96 MINN. L. REV. 2067 (2012). The leading case is Sony Corp. of America v. Universal City Studios, Inc., 464 U.S. 417 (1984). See also Fox Broad. Co. v. Dish Network L.L.C., 747 F.3d 1060 (9th Cir. 2013); Recording Indus. Ass'n of Am. v. Diamond Multimedia Sys., Inc., 18o F.3d 1072 (9th Cir. 1999).

13. L. Batlin \& Son, Inc. v. Snyder, 536 F.2d 486, 490 (2d Cir. 1976) (quoting 1 Melville B. NIMMER, NiMMER ON COPYRIGHT $§ 6$, at $10.2(1975)$ ). 
tension in her favor by means of fair use. ${ }^{14}$ After a few detours along the way, the courts have settled on asking whether the defendant's use is "transformative" of the plaintiff's expression. ${ }^{15}$ In the words of Judge Pierre Leval, who articulated the concept:

The use must be productive and must employ the quoted matter in a different manner or for a different purpose from the original. . . . If ... the secondary use adds value to the original-if the quoted matter is used as raw material, transformed in the creation of new information, new aesthetics, new insights and understandings-this is the very type of activity that the fair use doctrine intends to protect for the enrichment of society. ${ }^{16}$

Fair use in this vein turns on whether the defendant's use qualifies her as an author in her own right, one who stands on her own creative feet in crafting a work whose appeal to audiences derives from her own expression, rather than from the expression of the pre-existing materials she has recast and adapted.

This is the traditional shape of copyright: it protects humans writing for humans. Transformative fair users are simultaneously readers and authors; human authorship is ultimately about human readership. Some authorfocused accounts of copyright downplay the reader's agency in this engagement: she is treated "as a passive consumer of copyrighted works as entertainment commodities ... [who is] no different from the consumer of any other good." 17 But other accounts recognize that readers actively engage with works: they choose what, when, and how to read; they communicate with others with and about works; and they express themselves using works in ways that fall short of full authorship in the transformative-use sense. ${ }^{18}$ Scholars have described the richness of readers' experiences, emphasizing the ways in which reading is a human activity: it engages our facilities as thinking, feeling, embodied beings, and it is crucial to our development as fully realized and socially embedded individuals. ${ }^{19}$ These scholars agree that engagement with

14. See, e.g., ABraham DrassinOWER, What's WrOng WITH COPYING? 78 (2015) (“[T]he defense is not about undoing or overlooking a wrong for reasons extraneous to authorship itself. . . . It is as if, upon hearing the plaintiff's complaint, the defendant were to say: ' . . I am equally an author."”).

15. Authors Guild v. Google, Inc. (Authors Guild II), 804 F.3d 202, $214^{-1} 5$ (2d. Cir. 2015).

16. Pierre N. Leval, Commentary, Toward a Fair Use Standard, 103 HARV. L. REV. 1105,1111 (1990).

17. Joseph P. Liu, Copyright Law's Theory of the Consumer, 44 B.C. L. REV. 397, 402 (2003) (describing this as "the couch potato view" of readership).

18. Id. at $406-20$.

19. See, e.g., id.; Julie E. Cohen, The Place of the User in Copyright Law, 74 FORDHAM L. Rev. 347 (2005); Jessica Litman, Creative Reading, 7 O L. \& CONTEMP. ProbS., Spring 2007, at 175; Jessica Litman, Readers' Copyright, $5^{8}$ J. COPYRIGHT SOC'Y U.S.A. 325 (2011); Rebecca Tushnet, Copy This Essay: How Fair Use Doctrine Harms Free Speech and How Copying Serves It, 114 YALE L.J. 535 (2004). 
expression is the core of copyright; the difference is that they describe how copyright law can stand in the way of this engagement rather than promoting it. ${ }^{20}$ Copyright's friends, enemies, and frenemies alike tell a story about expressive reading. ${ }^{21}$

\section{ROBOTIC COPYRIGHT}

Digital technologies challenge this story in two respects. Qualitatively, they make it possible to use works in new ways; quantitatively, they make it possible to use works on a much greater scale. I would like to trace these two trends, and especially their intersection. When you combine nonexpressive uses and bulk copying, ${ }^{22}$ you obtain a form of reading that can only be carried out by robots. The idea of transformative fair use has itself been transformed to deal with such reading.

\section{A. NON-EXPRESSIVE READING}

Our point of departure is Sega $v$. Accolade. ${ }^{23}$ Accolade was a videogame publisher; it wanted to sell versions of its games that would run on a Sega Genesis console. ${ }^{24}$ Rather than pay a licensing fee to Sega, Accolade took three of Sega's games and reverse engineered them to understand the technical details of how they communicated with the Genesis. ${ }^{25}$ This process necessarily involved copying and analyzing large sections of the Sega games' software, but at the end of the process, Accolade's actual games included only trivially tiny excerpts from Sega's. ${ }^{26}$

Accolade's practice poses two challenges for a strict transformative fair use analysis. Accolade's games did not comment on or modify the expression in Sega's games in any meaningful sense, while its reverse engineering process involved extensive literal copying. Accolade thus made two uses, neither of which was a clear fit for transformative fair use. The games were too far removed from Sega's; the reverse engineering copies were too close.

20. See Yochai Benkler, Free as the Air to Common Use: First Amendment Constraints on Enclosure of the Public Domain, 74 N.Y.U. L. REV. 354, 354-57 (1999).

21. Professor Sag offers a useful distinction between "expressive" and "nonexpressive" uses. See Matthew Sag, Copyright and Copy-Reliant Technology, 103 NW. U. L. REV. 16o7, 1624-28 (2009); see also Maurizio Borghi \& Stavroula Karapapa, Non-Display Uses of Copyright Works: Google Books and Beyond, 1 QUEEN MARY J. INTELL. PROP. 21, 23, 43-44 (2011) (defining category of "non-display uses" and distinguishing "uses on works" from "uses of works").

22. See Matthew Sag, Orphan Works as Grist for the Data Mill, 27 Berkeley TeCH. L.J. 1503,

1548-49 (2012) (describing how bulk copying presents copyright issues).

23. Sega Enters. v. Accolade, Inc., 977 F.2d $15^{10}$ (9th Cir. 1992).

24. Id. at $15^{1} 4^{-15}$.

25. Id.

26. Id. at $15^{1} 5^{-16}$. 
The court's response was clear and sensible. Accolade's games had no need of fair use in the first place, ${ }^{27}$ while the reverse engineering was a form of "intermediate copying" protected by fair use. ${ }^{28}$ The copying was "the only way to gain access to the ideas and functional elements embodied in a copyrighted computer program." ${ }^{29}$ Accolade was like a book critic who starts by photocopying pages to spread on her floor as she annotates their inconsistencies and hypocrisies. Intermediate copying for a wholly noninfringing purpose is as permissible as intermediate copying for a transformatively fair one.

It is easy to see how Accolade fits cleanly into the conception of a creator rather than a slavish copyist. $3^{\circ}$ The court's reasoning, however, also says something about Accolade as a reader. Accolade's employees studied the Sega games closely, but not in the way a consumer would, by playing them for entertainment. Thus, Accolade was not using Sega's games for their protected expressive content, but simply to extract some unprotected, functional, nonexpressive information contained within them. The human audience at the end of the line-Accolade's customers-never received access to Sega's expression.

This is a lot to say about video games four generations out of date. But the conceptual twist in Sega v. Accolade is crucial, because it stands for the principle that non-expressive reading does not count as infringement. ${ }^{11}$ That principle is much broader than software; it applies whenever there is something to be learned about a copyrighted work other than its expressive authorship..$^{2}$ And that, as we will see, is all the time.

27. Id. at 1523-24 (assuming in passing that Accolade's games were "not substantially similar" to Sega's-and thus by implication were noninfringing).

28. Id. at $1521-28$.

29. Id. at 1527 .

3o. See id. at 1523 (describing Accolade's entry as motivated by a desire to become "a legitimate competitor in the field of Genesis-compatible video games").

31. See Sag, supra note 21, at 1639 (arguing for a "general principle of nonexpressive use" under which "acts of copying which do not communicate the author's original expression to the public should not be held to constitute copyright infringement").

32. It is also, in some respects, a narrower principle than intermediate copying. Consider Fox Broadcasting Co. v. Dish Network L.L.C., where the defendant sold digital video recorders capable of automatically skipping commercial breaks and also made "quality assurance" copies of television programs, used only internally at its own facilities, to ensure that the commercialskipping feature worked properly in consumers' homes. Fox Broad. Co. v. Dish Network L.C.C., 905 F. Supp. $2 d$ 1088, 1094-96 (C.D. Cal. 2012), aff'd, 747 F.3d 106o (9th Cir. 2013). The commercial skipping feature was fair use, so the logic of intermediate copying would have said that the quality assurance copies were too. $I d$. at 1106 . But the court held that they were not: They were commercial and non-transformative, and they threatened the market for the television programs. Id. at 1104-o6. Under the logic of non-expressive use, this result is easier to justify: The defendant's employees actually viewed the quality assurance copies, and they were used as part of a system helping consumers make expressive uses as well. 
The paradigm cases of transformative fair use involve partial or nonliteral copying: Portions of the old work are melted down and mixed with new elements to make authorship alloys.33 But another line of cases from the familiar world of humans writing for humans shows that even verbatim uses can be transformative-in Leval's terminology, the transformation consists of a "different purpose" rather than a "different manner." 34 The work is given to readers in essentially the same form, but for a very different reason than the one for which the work was created. It may be necessary to reproduce a work to prove that it exists, as in Núñez v. Caribbean International News Corp. 35 There, in reporting on a scandal involving nearly nude photographs of a beautypageant winner, a newspaper ran several of the photographs alongside its news articles. $3^{6}$ Held, fair use because "the pictures were shown not just to titillate, but also to inform." ${ }_{77}$ Or, as in Bill Graham Archives v. Dorling Kindersley $L t d$., the defendant may recontextualize a work by surrounding it with her own expression..$^{8}$ There, a publisher used reduced-size images of seven Grateful Dead concert posters as part of a 480 -page coffee-table book in the form of a timeline. 39 Held, the use of the images "as historical artifacts graphically representing the fact of significant Grateful Dead concert

33. See, e.g., Campbell v. Acuff-Rose Music, Inc., $5^{10}$ U.S. $5^{69}, 5^{83}$ (1994) (holding that 2 Live Crew's filthy rap version of the Roy Orbison song "Oh, Pretty Woman" was a parody and hence potentially transformative fair use).

34. See Leval, supra note 16 , at 1111 ; R. Anthony Reese, Transformativeness and the Derivative Work Right, 31 COLUM. J.L. \& ARTS 467,485 (2008) ("Though transformativeness for fair use analysis could involve both the purpose for which the defendant is using the copyrighted work and the alterations that the defendant has made to that work's content, the circuit court cases suggest that it is the former, rather than the latter, that really matters."). It is not obvious that all of these cases should be categorized as "transformative uses" under the first factor rather than harmless noncompeting uses under the fourth factor, but following Leval they have been. See Infinity Broad. Corp. v. Kirkwood, 15 o F.3d 104, 108 (2d Cir. 1998) (protesting, against the tide, that "difference in purpose is not quite the same thing as transformation" under Campbell); Neil Weinstock Netanel, Making Sense of Fair Use, 15 LeWIS \& Clark L. ReV. 715, 734-46 (2011) (tracing increasing dominance of first-factor "transformative use" paradigm over fourth-factor "market-centered" paradigm).

35. See Núñez v. Caribbean Int'l News Corp., 235 F.3d 18 (1 st Cir. 200o). But see Monge v. Maya Magazines, Inc., 688 F.3d 1164, 1176 (9th Cir. 2012) (finding that a gossip magazine's publication of photographs of a celebrity couple's secret wedding "did not transform the photos into a new work ... or incorporate the photos as part of a broader work"). Monge distinguished Núnez on the basis that the controversy there concerned "the salacious photos themselves." Monge, $688 \mathrm{~F} .3 \mathrm{~d}$ at 1175 . The newsworthiness fair use cases tend to be factually intensive. Compare, e.g., L.A. News Serv. v. Reuters Television Int'l, 149 F.3d 987 (9th Cir. 1998) (holding that a rebroadcast of a video clip of beating of Reginald Denny during the 1992 Los Angeles riots was not fair use), and L.A. News Serv. v. KCAL-TV Channel 9, 108 F.3d 1119 (9th Cir. 1997) (same), with L.A. News Serv. v. CBS Broad., Inc., 313 F.3d 1093 (9th Cir. 2002) (holding that a shorter use of the same clip was fair use).

36. Núñez, 235 F.3d at 21.

37. Id. at 22.

38. See generally Bill Graham Archives v. Dorling Kindersley Ltd., 448 F.3d 6o5 (2d Cir. 2006).

39. Id. at 607 . 
events ... fulfill[ed] [the defendant's] transformative purpose of enhancing the biographical information" in the book. $4^{\circ}$ Again, these cases easily fit the model of the transformative fair user as an author engaged in the process of creating "new information, new aesthetics, new insights and understandings." 41

Combine these different-purpose cases with Sega's idea of intermediate copying for nonexpressive uses and you end up with a powerful new principle. Verbatim copying of a complete work will be protected as fair use if the copy is used solely as input to a process that does not itself use the works expressively. Or, to put it a little more provocatively, nonexpressive uses do not count as reading. $4^{2}$ They are not part of the market that copyright cares about, because the author's market consists only of readers. 43

A string of recent cases, for example, deal with the reproduction of journal articles that are prior art for patent applications.44 The law firms preparing those applications have generally succeeded in arguing that their reproductions are fair use. Courts easily find that complying with the legal obligation to attach relevant prior art is a different purpose 45 But in denying that the law firms and the Patent Office are part of the audience the publishers intended to reach, the courts use language that starts to deny that they are audiences at all. One court explained that "[the law firm's] use of the Articles is narrower than, and indifferent to, their manner of expression." ${ }^{6}$ Another said that when an applicant submits prior art to the Patent Office, it "is transformed from an item of expressive content to evidence of the facts

40. Id. at 610 .

41. Leval, supra note 16 , at 1111 .

42. See DRASSINOWER, supra note 14 , at 87 ("[B] ecause a work is a communicative act, ... $[\mathrm{u}]$ ses of the work as a mere pattern of ink, so to speak, in the absence of recommunication, are not uses of the work as a work.").

43. Cf. Authors Guild, Inc. v. HathiTrust, 755 F.3d 87, 97 (2d Cir. 2014) ("There is no evidence that the Authors write with the purpose of enabling text searches of their books.").

44. E.g., Am. Inst. of Physics v. Winstead PC, No. 3:1 2-CV-1 230-M, 2013 WL 6242843 (N.D. Tex. Dec. 3, 2013); Am. Inst. of Physics v. Schwegman, Lundberg \& Woessner, P.A., No. 1 2-cv$5^{28}$ (RHK/JJK), 2013 WL $466633^{\circ}$ (D. Minn. Aug. 3o, 2013). Two similar cases failed to reach the fair use issue. See John Wiley \& Sons, Ltd. v. McDonnell Boehnen Hulbert \& Berghoff, LLP, No. 12 C 1446 (N.D. Ill. Mar. 25, 2014) (voluntarily dismissed); John Wiley \& Sons, Inc. v. Hovey Williams LLP, No. 5:2012-cv-4041 (D. Kan. June 22, 2012) (voluntarily dismissed). See generally D.R. Jones, Law Firm Copying and Fair Use: An Examination of Different Purpose and Fair Use Markets, 56 S. TEX. L. REV. 313 (2014) (discussing role of transformativeness in law firm copying cases).

45. Winstead, 2013 WL 6242843, at *5-6; Schwegman, Lundberg E Woessner, 2013 WL $466633^{\circ}$, at $* 9-13$.

46. Schwegman, Lundberg $\mathcal{E}^{\circ}$ Woessner, $2013 \mathrm{WL} 4666330$, at *12; accord Bond v. Blum, 317 F.3d 385,397 (4th Cir. 2003) (fair use to copy a manuscript for use in a child-custody proceeding); Denison v. Larkin, 64 F. Supp. 3d 1127,1135 (N.D. Ill. 2014) (fair use to copy blog post for use in an attorney discipline proceeding); Healthcare Advocates, Inc. v. Harding, Earley, Follmer \& Frailey, 497 F. Supp. 2d 627, 642 (E.D. Pa. 2007) (fair use to copy archived webpage for use in litigation). 
within it; the expressive content becomes merely incidental." 47 These cases speak in terms of transformation of the work, but the work itself changes only in the eye of the beholder: a different context or a different mode of reading. To say that a work is no longer "an item of expressive content" is to say that it is no longer being read expressively. $4^{8}$

\section{B. BULK READING}

Now it is time to pick up the other strand of our story: the shift from retail reading to wholesale. Take the search-engine cases, of which Perfect Io, Inc. $v$. Amazon.com is the leading example. 49 Google's image search engine copies millions of images from across the internet and shows small "thumbnails" of those images to users in response to search queries. $5^{\circ}$ This, the court held, was a transformative fair use, even though the thumbnails were exact replicas of the full-size images: "Although an image may have been created originally to serve an entertainment, aesthetic, or informative function, a search engine transforms the image into a pointer directing a user to a source of information." ${ }^{1}$ Note how search users are understood as readers. Google gives them access to the plaintiff's expressive works, but, in the act of using Google search, they are near-automatons. They follow a "pointer" supplied by an "electronic reference tool;"; $5^{2}$ any aesthetic appreciation is suspended until they arrive at their destination and admire the full-sized image in its original context. The court is able to elide the human audience by downplaying its humanity.53

A similar move is visible in A.V. ex rel. Vanderhye v. iParadigms. 54 There, high school students were required to submit their essays to a plagiarism-

47. Winstead, 2013 WL 6242843, at *5; accord Jartech, Inc. v. Clancy, 666 F.2d 403, 407 (9th Cir. 1982) (finding it was fair use to copy films "not for subsequent use and enjoyment, but for evidence to be used in [litigation]"); White v. W. Publ'g Corp., 29 F. Supp. 3d 396, 399-4oo (S.D.N.Y. 2014) (holding it was transformative fair use for West and Lexis to make comprehensive databases of filed legal briefs); Stern v. Does, 978 F. Supp. 2d 1031, 1045 (C.D. Cal. 2011)

(finding it was transformative fair use to forward an email because " $[\mathrm{b}] \mathrm{y}$ forwarding the post in e-mails, they conveyed the fact of the post rather than its underlying message").

48. Cf. DrassinOWER, supra note 14 , at 102 ("The defendant escapes liability not because her unauthorized use is fair but because it is not a use.").

49. See generally Perfect 10, Inc. v. Amazon.com, Inc., 508 F.3d $114^{6}$ (9th Cir. 2007).

5o. Id. at 1165; accord Kelly v. Arriba Soft Corp., 336 F.3d 811, 819 (9th Cir. 2002); Field v. Google Inc., 412 F. Supp. 2d 1106,1118 (D. Nev. 2006).

51. Perfect $10,508 \mathrm{~F} \cdot 3 \mathrm{~d}$ at 1165 .

52. Id.; see also Kelly, 336 F.3d at 819 (describing a search engine's purpose as "improving access to information on the internet [rather than] artistic expression").

53. Field v. Google Inc. is an interesting contrast. It dealt with Google's cache of archived webpages, and its fair use analysis emphasizes the interactive, mentally intense research tasks that users can make using the archived copies, including observing changes in a webpage over time and "understand[ing] why a page was responsive to their original query." Field, 412 F. Supp. 2d at $1118-19$.

54. A.V. ex rel. Vanderhye v. iParadigms, LLC, $5^{62}$ F.3d 630 (4th Cir. 20o9). 
detection service, Turnitin, which checked for suspicious similarity to essays already in the database, and then retained each essay to be checked against future essays. This, the court held, was a transformative fair use because Turnitin's use was "completely unrelated to expressive content." 55 The court emphasized Turnitin's use of robotic readers in a sentence that does not stand up to close reading: "The archived student works are stored as digital code, and employees of iParadigms do not read or review the archived works. ${ }^{6} 5^{6}$ The first half of this statement is trivially true: any work stored on a computer is stored as "digital code." And the second half should be irrelevant: if checking for plagiarism really is a transformative use, it shouldn't matter whether the comparisons are carried out by Turnitin's computers or its employees.

One of the Google Books cases, Authors Guild v. Google, takes the idea that bulk reading is not reading even further. ${ }^{57}$ Google's database of millions of scanned books supports a comprehensive search engine. In holding that the database is a "highly transformative" use, the court adopted Perfect ro's "pointer" theory: "Google Books . . . uses snippets of text to act as pointers directing users to a broad selection of books." ${ }^{8}$ The database also enables new uses in the "digital humanities" such as analyzing trends in word usage over time.59 But these uses do not count as infringements. To quote the court, "Google Books does not supersede or supplant books because it is not a tool to be used to read books." ${ }^{\circ o}$ In affirming this holding on appeal, Judge Leval himself wrote, "What matters in such cases is not so much "the amount and substantiality of the portion used' in making a copy, but rather the amount and substantiality of what is thereby made accessible to a public for which it may serve as a competing substitute." 61

Another strand of the Google Books litigation-against Google's partner libraries-reaches the same idea indirectly. ${ }^{62}$ The authors had argued that the libraries' database of digitized books created a security risk that hackers would break in and copy the books. The court disagreed, describing the risk as "hypothetical" and "speculative." ${ }_{3}$ Note the framing. It was undisputed that there were at least four different physical instantiations of millions of books. But those copies did not count because there was no evidence in the record

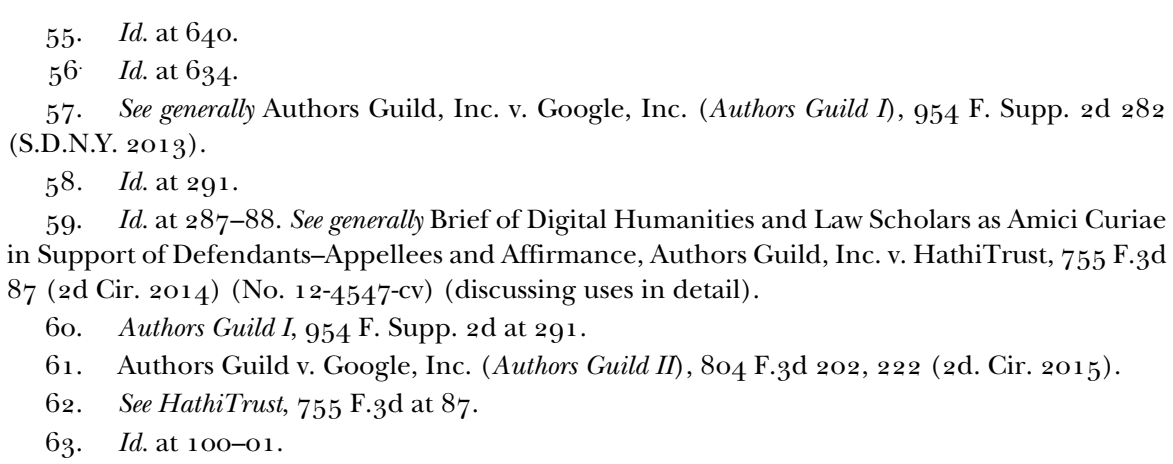


that any humans were likely to read them. To similar effect is the District Court's opinion in Cambridge University Press v. Becker, which held that uploading book excerpts to a university's electronic reserves site was a noninfringing de minimis use where no students ever downloaded the excerpts. ${ }^{6} 4$ If a copy falls in the forest and no humans are there to hear it, the sound is non-infringing. Bulk nonexpressive uses are fair uses.

When we talk about nonexpressive uses, we should perhaps refer to them by another name: non-human uses. When we as people take part in these uses, we suspend our human capacities. The now-rejected Google Books settlement inadvertently captured this idea when it defined (permissible) "NonConsumptive Research" as "research in which computational analysis is performed on one or more Books, but not research in which a researcher reads or displays substantial portions of a Book to understand the intellectual content presented within the Book." ${ }_{5}$ You can only read this book if you don't understand anything in it.

Perhaps you have seen the tension. We have created a two-tracked copyright law: one for human readers and one for robots. Uses involving human readers receive close and exacting scrutiny to make sure that no market belonging to the copyright owner is being preempted. Uses involving robotic readers are fast-tracked for fair use.

A pair of recent cases illustrates the difficulties this divergence creates. Both involve news-monitoring services. Meltwater scrapes news articles from 162, ooo websites, indexes them, and delivers alerts to its customers when new stories appear on particular topics. ${ }^{66}$ TVEyes does the same for television and radio news from 1400 stations. ${ }^{67}$ In both cases, news-media plaintiffs argued that the services were infringing republishers of copyrighted news stories; both services defended themselves by arguing that they were search engines. Both cases turned on fair use; Meltwater's use was nontransformative and lost, ${ }^{68}$ while TVEyes' use was transformative and won. ${ }^{69}$ The difference between Meltwater and TVEyes consists not of their facts-which, while in theory distinguishable, are in truth uncomfortably close-but in the different

\footnotetext{
64. Cambridge Univ. Press v. Becker, 863 F. Supp. 2d 119o, 1245-53, 1265, 1298, 1314 , 1337 (N.D. Ga. 201 2), rev'd on other grounds sub nom. Cambridge Univ. Press v. Patton, 769 F.3d 1232 (11 th Cir. 2014). An instructive contrast is Ringgold v. Black Entertainment Television, Inc., which held that an out-of-focus poster visible in the background of a sitcom episode for a total of 26.75 seconds was not a de minimis use. The poster was visible only fleetingly, but it was still visible to the human audience-and that makes all the difference. See Ringgold v. Black Entertainment Television, Inc., 126 F.3d 7o, $76-77$ (2d Cir. 1997).

65. Amended Settlement Agreement § 1.93, Authors Guild v. Google Inc., 77o F. Supp. 2d 666 (S.D.N.Y. 2011 ) (No. 05 Civ. 8136 (DC)).

66. Associated Press v. Meltwater U.S. Holdings, Inc., 931 F. Supp. $2 d$ 537, 543-44 (S.D.N.Y. 2013).

67. Fox News Network, LLC v. TVEyes, Inc., 43 F. Supp. 3d 379, 383 (S.D.N.Y. 2014).

68. Meltwater, 931 F. Supp. 2 d at $55^{2}$.

69. TVEyes, 43 F. Supp. $3 \mathrm{~d}$ at 400.
} 
way they conceptualize what these aggregation services do. In Meltwater, Judge Cote sees Meltwater as a service for human readers; it helps them organize and optimize their consumption of news. $7^{\circ}$ In TVEyes, Judge Hellerstein sees TVEyes as a digital service whose operations are at heart non-human. ${ }^{71}$ Watching a thousand channels full-time forever is a task that is so far beyond the capacity of any person that it is simply "different in kind." $7^{2}$ Take that, John Henry.

\section{BEYOND FAIR USE}

I have dwelt at length on transformative fair use, because it seems to me that here the pattern of denigrating robotic reading is at its clearest and most dramatic. But something similar is at work in other parts of copyright doctrine. Activities that copyright forbids to humans escape its notice when they are carried out by robots.

Consider the history of how copyright has treated works and copies created to be read by robots. That history goes back surprisingly far, because the 19th century had copyright-infringing robots too-player pianos. In a string of cases culminating in 19o8's White-Smith Music Publishing Co. v. Apollo Co., the courts held that the perforated paper rolls used by player pianos were not infringing "copies within the meaning of the copyright act." 73 Their reasoning was explicitly anthropocentric: the piano rolls were "part of a machine" rather than being "addressed to the eye."74 Unlike sheet music that humans can make sense of, the rolls could be read only by robots: they "[c] onvey[ed] no meaning . . . to the eye of even an expert musician." 75 The Supreme Court rhetorically asked whether Congress could have meant to subject mere "instruments" like music box cylinders and phonograph records to copyright. $7^{6}$

The next year, Congress did just that, because of course player pianos produce sounds for the human ear even if their rolls are not addressed to the

70. See Meltwater, $93^{1}$ F. Supp. 2d at $55^{2}$ (quoting Meltwater marketing materials as saying "your news is delivered in easy to read morning and/or afternoon reports").

71. See TVEyes, 43 F. Supp. 3d at 393 ("Thus, without TVEyes, this information cannot otherwise be gathered and searched. That, in and of itself, makes TVEyes' purpose transformative ... .”); accord White v. W. Publ'g Corp., 29 F. Supp. 3d 396, 399-40o (S.D.N.Y. 2014) (finding that copying legal briefs to create an "interactive legal research tool" was fair use).

72. TVEyes, 43 F. Supp. 3d at 393 ("Meltwater aggregated content already available to the individual user who was willing to perform enough searches and cull enough results on the Internet. . . TVEyes, however, creates a database of otherwise unavailable content. TVEyes is the only service that creates a database of everything that television channels broadcast, twenty-four hours a day, seven days a week.”).

73. White Smith Music Publ'g Co. v. Apollo Co., 209 U.S. 1, 18 (1908).

74. Id. at 12 (quoting Kennedy v. McTammany, 33 F. 584,584 (C.C.D. Mass. 1888 )).

75. Id. at 13 (quoting Stern v. Rosey, 17 App. D.C. $5^{62}, 5^{6} 5$ (D.C. Cir. 1901 )).

76. Id. at 17-18. Note the dual meaning of "instrument" -it is both something that produces music and merely a means for accomplishing a task. Id. at 17 . 
human eye. The Copyright Act of 1909 extended the copyright owner's exclusive rights to "any form of record in which the thought of an author may be recorded and from which it may be read or reproduced." 77 But the idea persisted that copies intended to be read by machines were subordinate to copies intended to be read by humans. The 1909 Act subjected these "mechanical reproductions" to a statutory compulsory license, $7^{8}$ one that endures today. 79 Even when they directly facilitate human reading, copies for robots have second-class status in copyright's ontology.

Something similar happened with computer software. Programs are written by humans to be read by robots: romantic authorship without romantic readership. This creates a conceptual barrier to software copyright over and above the usual debates about authorship and economics. ${ }^{80}$ Thus, in dissent from the Commission on New Technological Uses ("CONTU") report recommending copyright protection for computer software, commissioner and novelist John Hersey argued that programs "eventually become an essential part of the machinery" of a computer, ${ }^{81}$ are not "intelligible to a human being," ${ }_{2}$ and are "not designed to be read by anyone." ${ }_{3}$ He concluded that software copyright meant "affording copyright protection to a laborsaving mechanical device." ${ }_{4}$ His colleague, the copyright scholar Melville Nimmer, suggested that "it may prove desirable to limit copyright protection for software to those computer programs which produce works which themselves qualify for copyright protection" - that is, to programs which emit something human audiences would recognize as authorial expression..$^{85}$ Another line of defense was that only source code-the human-written and

77. Copyright Act of 1909, Pub. L. No. 6o-349, § 1(e), 35 Stat. 1075, $1075^{-76}$. The 1976 Copyright Act embraced this principle: a work is "fixed" in a "copy" when it "can be perceived, reproduced, or otherwise communicated, either directly or with the aid of a machine or device." 17 U.S.C. $\$ 101$ (2012). The use of "perceived" shows that the link to human perception remains. A work is fixed only when humans could ultimately perceive it, even if indirectly.

78. Copyright Act of $1909 \S 1$ (e), 35 Stat. at $1075^{-76}$.

79. 17 U.S.C. $\$ 115$ (2012). It has been joined by other statutory licenses directed at robots. See id. \$112 ("ephemeral" copies made by broadcasters); $i d . \$ 114$ (j) ("noninteractive" digital audio transmissions); $i d . \S 116$ ("phonorecord players" such as jukeboxes).

8o. The major doctrinal problem for authorship is that much of what goes into a computer program is heavily influenced or even dictated by functional constraints. On the authorship and policy questions, compare, for example, Arthur R. Miller, Copyright Protection for Computer Programs, Databases, and Computer-Generated Works: Is Anything New Since CONTU?, 106 HARV. L. REV. 977, 1059 (1993), with Pamela Samuelson, CONTU Revisited: The Case Against Copyright Protection for Computer Programs in Machine-Readable Form, 1984 DUKE L.J. 663, 753.

81. NAT'L COMM'N ON NEW TECH. USES OF COPYRIGHTED WORKS, FINAL REPORT OF THE National Commission on NeW TeChNOlogical Uses of COPYRIGHTED WORKS 28 (1979)

(Hersey, Comm'r, dissenting) (emphasis omitted).

82. Id. at 29 .

83. Id. at 30 .

84. Id.

85. Id. at 27 (Nimmer, Comm'r, concurring). 
human-intelligible texts written by programmers-should be eligible for copyright protection, but not the object code actually executed by computers. ${ }^{86}$

These categorical arguments against software copyright have not fared well; $; 7$ it is clear today that computer programs are proper copyrightable subject matter ${ }^{88}$ and that running a program creates a potentially infringing copy. ${ }^{89}$ The debates in the courts instead mostly turn on case-by-case questions of which specific aspects of a particular program are copyrightable. $9^{\circ}$ This might seem to count against the argument that robotic reading is noninfringing. But consider this: Congress carved out (albeit clumsily) an exception for copies of computer programs "created as an essential step in the utilization of the computer program in conjunction with a machine and ... used in no other manner." ${ }^{11}$ The idea that robot-only copying is different lives on. More fundamentally, it is these broad rules-programs are copyrightable, and running a program infringes the reproduction right-that have made it necessary to invoke fair use as a defense in technological cases. The story told above about transformative fair use is the story of how the courts used fair use to shield robotic reading from liability that would otherwise attach. Exempting robots entirely would have led to the White-Smith problem: uses indisputably intended for human eyes would escape scrutiny. The combination of broad infringement and broad fair use draws the line instead between robot-only and robot-plus-human uses.

Copyright embraces the rule that robotic reading does not count in many other contexts, as well. Here are a few.

Volitional Conduct: " $[\mathrm{S}]$ omething more must be shown than mere ownership of a machine used by others to make illegal copies" to hold a

86. See, e.g., Williams Elecs., Inc. v. Artic Int'l, Inc., $68_{5}$ F.2d 87o, 876-77 (3d Cir. 1982) (rejecting defendant's theory "that a 'copy' must be intelligible to human beings").

87. The Commission's report rejected Hersey and Nimmer's misgivings, reasoning that a computer program in computer memory "still exists in a form from which a human-readable version may be produced” regardless of what the program does. NAT'L COMM'N ON NEW TECH. USES OF COPYRIGHTED WORKS, supra note 81, at 22. Even for the Commission at its most expansive, man was still the measure of all things.

88. See Apple Comput. Inc. v. Franklin Comput. Corp., 714 F.2d 1240,1248 (3d Cir. 1983) (rejecting the argument "that copyrightability depends on a communicative function to individuals"); NAT'L COMM'N ON NEW TECH. USES OF COPYRIGHTED WORKS, supra note 81, at 22.

89. MAI Sys. Corp. v. Peak Comput., Inc., 991 F. $2 d 5^{11}, 5^{1} 8$ (9th Cir. 1993). But see Cartoon Network LP v. CSC Holdings, Inc., 536 F.3d 121 , 1 29-3o (2d Cir. 2008) (holding that data stored in computer memory for 1.2 seconds is not sufficiently "embodied . . f for a period of more than transitory duration" to infringe).

9o. See, e.g., Comput. Assocs. Int'l, Inc. v. Altai, Inc., 982 F.2d 693, 7o6-11 (2d Cir. 1992) (giving detailed analytical framework for assessing infringement of software); Oracle Am., Inc. v. Google, Inc., 872 F. Supp. 2d 974, 977 (N.D. Cal. 2012) (rejecting copyright in software interfaces), rev'd, $75^{\circ}$ F.3d 1339, $134^{8}$ (Fed. Cir. 2014) (allowing copyright in those same software interfaces).

91. 17 U.S.C. $\$ 117(\mathrm{a})(1)(2012)$. 
defendant directly liable as an infringer. $9^{2}$ The defendant must have "some aspect of volition and meaningful causation-as distinct from passive ownership and management of an electronic Internet facility." 93 Unlike the transformative fair use defense, which fully excuses an otherwise-infringing act, the volitional conduct doctrine is a rule of attribution: It decides which of several possible defendants should be treated as a direct infringer. But it still offers strong advantages to defendants who can invoke it, because copyright's various secondary liability tests are far more protective of defendants than its "strict liability" direct infringement test.94 The result is another strong pressure to automate. Employees can have volition; computers cannot. It is not a coincidence that the volitional conduct defense arises only in cases involving computers.

Online Intermediaries: The safe harbor for online content hosts in $\S 5^{12}$ (c) of the Copyright Act draws on the same ideas. The safe harbor is available only to "a provider of online services or network access" 95 and only when the provider "does not have actual knowledge" 96 of infringement and "is not aware of facts or circumstances from which infringing activity is apparent."97 Again, these tests encourage automation. The threshold condition makes the safe harbor inapplicable if an enterprise doesn't use computers. Once the enterprise uses computers, the knowledge tests

92. CoStar Grp., Inc. v. LoopNet, Inc. 373 F.3d 544, $55^{\circ}$ (4th Cir. 2004); accord Fox Broad. Co. v. Dish Network LLC, 723 F.3d 1067, 1073 (9th Cir. 2013); Cartoon Network LP v. CSC Holdings, Inc., 536 F.3d 121 , 131 (2d Cir. 20o8); Parker v. Google Inc., 242 F. App'x 833, 837 (3d Cir. 2007); Disney Enters., Inc. v. Hotfile Corp., 798 F. Supp. 2d 1303, 1308 (S.D. Fla. 201 1); Marobie-FL, Inc. v. Nat'l Ass'n of Fire Equip. Dists., 983 F. Supp. 1167,1178 (N.D. Ill. 1997); Playboy Enters., Inc. v. Russ Hardenburgh, Inc., 982 F. Supp. 503, $5^{12}$ (N.D. Ohio 1997).

93. CoStar Grp., 373 F.3d at $55^{\circ}$.

94. Compare Metro-Goldwyn-Mayer Studios Inc. v. Grokster, Ltd., 545 U.S. 913 , 919 (2005) (finding inducement copyright liability requires both the intent to promote infringement and "clear expression or other affirmative steps taken to foster infringement"), Sony Corp. of Am. v. Universal City Studios, Inc., 464 U.S. $417,44^{2}$ (1984) (holding that the sale of copying equipment cannot give rise to contributory liability where the device is "capable of substantial noninfringing uses"), A\&M Records, Inc. v. Napster, Inc., 239 F.3d 1004, 1019 (9th Cir. 2001) (stating that contributory copyright liability requires both knowledge of the infringing activity and a material contribution to it), and $i d$. at 1022 (stating that vicarious copyright liability requires both "the right and ability to supervise the infringing activity and . . a direct financial interest in [it]" (quoting Fonovisa, Inc. v. Cherry Auction, Inc., 76 F.3d 259, 262 (9th Cir. 1996)) ), with Jacobs v. Memphis Convention \& Visitors Bureau, 710 F. Supp. 2d 663, 677 n.21 (W.D. Tenn. 2010) (stating, in a direct infringement case, "[c] opyright infringement, however, is at its core a strict liability cause of action, and copyright law imposes liability even in the absence of an intent to infringe the rights of the copyright holder"); and Fred Fisher, Inc. v. Dillingham, 298 F. 145, 148 (S.D.N.Y. 1924) (holding that defendant could be liable for copying the plaintiff's song without realizing it because "[o]nce it appears that another has in fact used the copyright as the source of his production, he has invaded the author's rights ... . It is no excuse that in so doing his memory has played him a trick").

95. 17 U.S.C. $\$ 5^{12(k)(1)(B) .}$

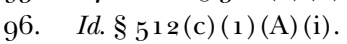

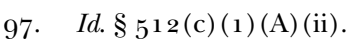


discourage it from looking too closely at what those computers are doing, lest it acquire the kind of knowledge that could lead it to lose the safe harbor's protections..$^{8}$ YouTube's Content ID system for detecting infringing uploads is the logical extrapolation of this trend: a wholly automated system that takes humans completely out of the loop.99 The $\S 5^{12}$ (a) safe harbor for network operators is even more dramatic: it applies only to "an automatic technical process" that operates only as "an automatic response." ${ }^{100}$ No humans need apply.

Takedown Notices: The same is true on the other side of the takedown wars. Copyright owners can in theory face liability if they send takedown notices falsely alleging that "material or activity is infringing." ${ }^{101}$ But since the test for liability is whether one "knowingly materially misrepresents," a copyright owner who avoids knowing that a dodgy notice is false can send it without fear. ${ }^{102}$ To be sure, a copyright owner may not simply fire off takedown notices without considering defenses such as fair use. ${ }^{103}$ But since the standard for forming the necessary "good faith belief" of infringement is subjective rather than objective, any review process at all will suffice. ${ }^{104}$ The incentives are obvious. Use robots to identify potentially infringing material, casting as wide a net as possible, then pass the results by humans for a review so cursory there is no risk they will notice they are sending a takedown notice for papers by Professor Peter Usher rather than songs by Usher the musician. ${ }^{105}$ A heavily automated process is far less risky than one in which humans provide meaningful review; indeed, it is best to reduce the humans' cognitive role to the point that their intervention is indistinguishable from a cricket jumping up and down on a mouse button. ${ }^{106}$ In a reductio ad absurdum

98. For a more sophisticated discussion of when it makes sense to impute knowledge to the operator of a program, see SAMIR CHOPRA \& LAURENCE F. White, A LEgAL THEORY FOR AutONOMOUS ARTIFICIAL AgENTS 71-118 (2011).

99. See generally How Content ID Works, YOUTUBE, https://support.google.com/youtube/ answer $/ 279737 \mathrm{O}$ ?hl=en (last visited Nov. 13, 2015).

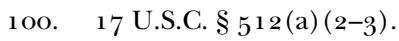

101. Id. $\S 5^{12}(\mathrm{f})(1)$.

102. Id. $\$ 5_{12}(\mathrm{f})$.

103. Lenz v. Universal Music Corp., 8o1 F.3d $1126,1136-37$ (9th Cir. 2015).

104. Id. at 1136 .

105. See Declan McCullagh, RIAA Apologizes for Threatening Letter, CNET NEWS (May 13, 2003, 6:1 2 PM), http://www.cnet.com/news/riaa-apologizes-for-threatening-letter.

106. See, e.g., Disney Enters., Inc. v. Hotfile Corp., No. 11-20427-CIV-WILLIAMS, slip op. at 31, 97 (S.D. Fla. Sept. 20, 2013) (describing DMCA takedown issuance process which "relied on computer automation to execute programs and did not involve human review of the file titles, page names or other overt characteristics" but declining to rule on existence of a duty for human review because of evidence that the movie studio "intentionally targeted files it knew it had no right to remove"). 
of this process, laser printers have received takedown notices-robots accusing each other of copyright infringement. ${ }^{107}$

Compare this attitude toward robotic readership with copyright's treatment of robotic authorship; the scholarly consensus is that computers can't be authors, either. The (human) programmer might be an author; the (human) user might be an author, but not the program that connects them. Pamela Samuelson argued in 1986 that computers have not been and should not be treated as authors, because they do not need incentives to create. ${ }^{108}$ Ralph Clifford similarly argued in 1997 that because computer programs cannot be "authors" in a statutory sense, computer-created works are uncopyrightable. ${ }^{109}$ And in 2012, Annmarie Bridy added that our copyright system "cannot vest ownership of the copyright" in a computer that "has no legal personhood." ${ }^{110}$ Bridy recommends using the "legal fiction" of the workmade-for-hire doctrine to avoid the conceptual issues: find a person and attribute to them ownership of a work they did not actually write. ${ }^{111}$ Robot readers can't infringe, and we won't let robots be authors, either. ${ }^{112}$

Copyright is not the only field of law to flirt with the idea that what happens in silicon stays in silicon. Google has defended itself against privacy lawsuits by claiming that when it targets advertisements to Gmail users, only computers, not humans, "read" users' emails. ${ }^{113}$ The NSA has likewise argued

107. See Michael Piatek et al., Challenges and Directions for Monitoring P2P File Sharing Networksor-Why My Printer Received a DMCA Takedown Notice, 3 PROC. USENIX WORKSHOP ON HOT TOPICS SECURITY 1, 3 (2008), http://usenix.org/legacy/events/hotseco8/tech/full_papers/piatek/ piatek.pdf; Brad Stone, The Inexact Science Behind D.M.C.A. Takedown Notices, N.Y. TIMES: BITS BLOG (June 5, 2008, 11:18 AM), http://www.bits.blogs.nytimes.com/2008/o6/o5/the-inexact-sciencebehind-dmca-takedown-notices; $c f$. Kashmir Hill, After Twitter Bot Makes Death Threat, Its Owner Gets Questioned by Police, FusION (Feb. 11, 2015, 8:46 AM), http://www.fusion.net/story/47353/ twitter-bot-death-threat.

108. Pamela Samuelson, Allocating Ownership Rights in Computer-Generated Works, 47 U. PITT. L. REV. $118_{5}, 1199$ (1986).

109. Ralph D. Clifford, Intellectual Property in the Era of the Creative Computer Program: Will the True Creator Please Stand Up?, 71 TuL. L. REv. 1675, 1682-86 (1997).

110. Annemarie Bridy, Coding Creativity: Copyright and the Artificially Intelligent Author, 2012 STAN. TECH. L. REV. 5 , I $5^{1}$; accord Miller, supra note 80.

111. Bridy, supra note 110 , II $5^{1-52 ; c f . ~ i d . ~ I ~} 67$ (discussing analogous approaches under U.K., New Zealand, and Irish law, according to which "copyright vests as a matter of law in a party who is not the author-in-fact").

112. See Evan H. Farr, Copyrightability of Computer-Created Works, 15 RUTGERS COMPUTER \& TECH. L.J. 63, 79 (1989) ("Giving authorship rights to a computer, however, is absurd ...."). The demands copyright makes of human authors, on the other hand, are notoriously minimal. See, e.g., Alfred Bell \& Co. v. Catalda Fine Arts, Inc., 191 F.2d 99, 102-03 (2d Cir. 1951) ("All that is needed to satisfy both the Constitution and the statute is that the 'author' contributed something more than a 'merely trivial' variation, something recognizably 'his own.' Originality in this context 'means little more than a prohibition of actual copying.' No matter how poor artistically the 'author's' addition, it is enough if it be his own.").

113. See Bruce E. Boyden, Can a Computer Intercept Your Email?, 34 CARDOZO L. Rev. 669, 673-74 (2012); Samir Chopra \& Laurence White, Privacy and Artificial Agents, or, Is Google Reading My Email?, 2007 INT'L JOINT CONF. ON ARTIFICIAL INTELLIGENCE 1245. 
that it does not "acquire" private communications unless and until an employee reads them. ${ }^{114}$ The rise of high-speed trading algorithms raises uncomfortable questions about whether a computer can have the requisite mental state to "knowingly" engage in market manipulation ${ }^{115}$ or to enter into an "agreement" to fix prices. ${ }^{116}$ And Swiss authorities didn't bother trying to sort out the philosophical questions posed by a drug-buying robot; ${ }^{117}$ they simply seized the robot. ${ }^{118}$ But to my knowledge, copyright is the only field of law to so thoroughly and whole-heartedly embrace the idea that robots simply do not count.

\section{Posthuman COPYRight}

Copyright ignores robots. This choice is entirely consistent with copyright's theory of the romantic reader. It is amply supported by fair use doctrine. And it yields sensible results in the cases that have come before the courts. But there is something unsettling about a rule of law that regulates humans and gives robots free rein. Most immediately, it encourages people and businesses to outsource their reading. To the extent that the rule depends on the inhuman scale of robotic reading, it also encourages them to scale up their copying. Rebroadcast one radio station for humans and you're an

1 14. See Kevin Bankston \& Amie Stepanovich, When Robot Eyes Are Watching You: The Law \& Policy of Automated Communications Surveillance 9 (July 2014) (unpublished manuscript), http://robots.law.miami.edu/2014/wp-content/uploads/2014/o7/Bankston_Stepanovich_We_

Robot.pdf. Compare Orin S. Kerr, Searches and Seizures in a Digital World, 119 HARV. L. REV. 531, $548(2005)$ (" $[\mathrm{A}]$ search of data stored on a hard drive occurs when that data, or information about that data, is exposed to human observation."), and Matthew Tokson, Automation and the Fourth Amendment, 96 IOWA L. REV. 581, $5^{87}$ (2011) ("Internet users do not suffer a cognizable privacy harm in the absence of some eventual disclosure to a human observer."), with Bankston \& Stepanovich, supra, at 3 ("[T] he mere fact that the act of reading the emails is automated does not decrease the invasiveness of that act, but instead intensifies the privacy invasion by exponentially increasing the accuracy, speed, and scope of surveillance."), and Jonathan Zittrain, Searches and Seizures in a Networked World, 119 HARV. L. REV. F. 83, 90 (2006) ("The shift from local to network storage also compels skepticism of the idea that mirroring of private data by the government [i.e., without exposure to a human] is not itself a search.").

115. See, e.g., Gregory Scopino, Do Automated Trading Systems Dream of Manipulating the Price of Futures Contracts? Policing Markets for Improper Trading Practices by Algorithmic Robots, 67 FLA. L. REV. 221, 233-34 (2015).

116. See Salil K. Mehra, Antitrust and the Robo-Seller: Competition in the Time of Algorithms, 100 MINN. L. REV. (forthcoming 2015) (manuscript 39-42) (Legal Studies Research Paper Series, Research Paper No. 2015-15), http://papers.ssrn.com/sol3/papers.cfm?abstract_id=2576341.

1 1 7. Ryan Calo, A Robot Really Committed a Crime: Now What?, FORBES (Dec. 23, 2014, 5:04 PM), http://www.forbes.com/sites/ryancalo/2014/12/23/a-robot-really-committed-a-crime-now-what; see also Mike Power, What Happens When a Software Bot Goes on a Darknet Shopping Spree?, GuARDIAN (Dec. 5, 2014, 8:56 AM), http://www.theguardian.com/technology/2014/dec/o5/software-botdarknet-shopping-spree-random-shopper.

1 18. See Daniel Rivero, Robots Are Starting to Break the Law and Nobody Knows What to Do About It, Fusion (Dec. 29, 2014, 8:14 AM), http://fusion.net/story/35883/robots-are-starting-to-breakthe-law-and-nobody-knows-what-to-do-about-it. 
infringer; copy a thousand TV stations for computers and you're a fair use hero. ${ }^{119}$

This pressure to use robots is indifferent to whether people use robots for good or for ill. It is easy to see the value of digital humanities research. But not all robotic reading is so benign, and the logic of nonexpressive use encourages the circulation of copyrighted works in an underground robotic economy. Take spambots, which profligately recycle everything from Shakespeare to sports stories into a semantic soup designed to trick other robots-spam filters-into showing their emails to a human user. ${ }^{120}$ If we take the robotic-reader cases at face value, spam filters are noninfringing fair users-and so are spambots. ${ }^{121}$ Perhaps copyright is the wrong tool for stopping spam, ${ }^{122}$ but a rule of law giving spambots free rein is certainly an odd consequence of robotic readership.

The paradox goes deeper. By valorizing robotic reading, copyright doctrine denigrates human reading. A transformative fair use test that categorically exempts robots means that a digital humanist can skim a million books with abandon while a humanist who reads a few books closely must pay full freight for hers. Romantic readership therefore discourages the personal engagement with a work that it claims to value. Copyright's expressive message here-robots good, humans bad-is the exact opposite of the one it means to convey.

Indeed, by embracing robotic reading, copyright may also change the nature of human reading. Robotic reading is a form of automation, and as such, it must confront familiar critiques of automation's effects on humans. ${ }^{123}$ Ask a spell-checker to do your proofreading for you often enough and your own ability to proofread will atrophy from disuse. ${ }^{124}$ Google Translate reads superficially and in fragments; its translations aren't great, but they're good enough to make professional translators worried about the future of their

\footnotetext{
1 19. Compare Infinity Broad. Corp. v. Kirkwood, $15^{\mathrm{o}} \mathrm{F} .3^{\mathrm{d}} 104,106$ (2d Cir. 1998) (finding it was infringement to "enable[] subscribers (for a fee) to listen over the telephone to contemporaneous radio broadcasts in remote cities"), with Fox News Network, LLC v. TVEyes Inc., 43 F. Supp. 3d 379, 393 (S.D.N.Y. 2014) (finding it was not infringement to create "a database of everything that television channels broadcast, twenty-four hours a day, seven days a week").

120. See generally Finn BRUnTON, SPAM: A SHAdOW HiSTORY OF THE INTERNET 143-61 (Geoffrey Bowker \& Paul N. Edwards eds., 2013).

121. Compare SPAM POETRY INSTITUTE, http://www.spampoetry.org (collecting examples of accidental poetry in computer-generated emails), with Bridy, supra note 110, II 22-40 (describing examples of more deliberate computational creativity).

122. Cf. Rebecca Bolin, Opting Out of Spam: A Domain Level Do-Not-Spam Registry, 24 YALE L. \& POL'Y REV. 399, 413 (2006) (describing failure of Habeas, a business that embedded a copyrighted haiku in legitimate emails and sued spammers who copied the haiku).

123. See generally NiCHOLAS CARR, THE GLASS CAGE: AUTOMATION AND Us (2014); JARON LANIER, YOU ARE NOT A GADGET: A MANifESTO (2010).

124. CARR, supra note 123 , at $65^{-85}$ (discussing automation bias, automation complacency, and degeneration). See generally NichOlas CARR, THE SHALlOWS: WHAT THE INTERnET Is DOING TO OUR BRAINS (2011) (discussing troubling cognitive effects of extensive computer use).
} 
profession. ${ }^{125}$ CAPTCHAs and Amazon Mechanical Turk ask humans to read like robots: superficially, repetitively, and in microscopic bursts. ${ }^{126}$ None of these possible futures of reading is particularly appealing from the standpoint of romantic readership. ${ }^{127}$

Or look even further ahead. Copyright's tolerant attitude towards robotic reading has fueled a global effort to make communications robot-readable. ${ }^{128}$ All human expression is "grist for the data mill." ${ }^{129}$ We are teaching robots to

125. See, e.g., Nicholas OSTler, The LAST LinguA Franca: ENGLiSh UnTIL THE RETURN OF BABEL, at xix (2010) (predicting that machine translation may "remove[] the requirement for a human intermediary to interpret or translate"); $c f .17$ U.S.C. \$101 (2012) (defining "derivative work" to include "a translation"). Compare MARTIN FORD, RISE OF THE ROBOTS: TECHNOLOGY AND The Threat of A Jobless Future (2015), and Humans Need Not Apply, C.G.P. Grey (Aug. 13, 2014), http://www.cgpgrey.com/blog/humans-need-not-apply (predicting significant structural unemployment from computerization), with ERIK BRYNJOLFSSON \& ANDREW MCAFEE, THE SECOND Machine AgE: Work, Progress, AND ProsPerity in A Time OF BRILliant TeCHNOLOGIES (2014) (predicting disruptive shifts in employment but more optimistic overall). See generally Frank LeVy \& Richard J. Murnane, The NeW Division of LABOR: How Computers ARE CREATING THE NEXT JOB MARKET (2012) (discussing types of labor that are and are not vulnerable to automation); Christopher STEIner, Automate This: How Algorithms CAME TO Rule OUR WORLD (2012) (providing case studies of computerization); Carl Benedikt Frey \& Michael A. Osborne, The Future of Employment: How Susceptible Are Jobs to Computerisation?, OXFORD MARTIN SCH. (Sept. 17, 2013), http://www.oxfordmartin.ox.ac.uk/downloads/academic/The_Future_ of_Employment.pdf.

126. See Ayhan Aytes, Return of the Crowds: Mechanical Turk and Neoliberal States of Exception, in Digital Labor: The InTERnet as Playground And FACTORY 79, 91 (Trebor Scholz ed., 2013) (describing "exploitative aspects of cognitive labor arbitrage"); Miriam A. Cherry, Working for (Virtually) Minimum Wage: Applying the Fair Labor Standards Act in Cyberspace, 6o ALA. L. REV. 1077, 1089-92 (2009) (discussing employment law issues). For an example of human "reading" in an age of robots, consider the people who are paid to turn the pages for Google's book-scanning robots. The mechanical nature of their work excludes this "yellow badge class" from the perks lavished on Google's regular white-badge employees; they work in different buildings under topsecret conditions. See Andrew Norman Wilson, Workers Leaving the Googleplex, ANDREW NORMAN WILSON, http://www.andrewnormanwilson.com/WorkersGoogleplex.html (last visited Nov 13, 2015). The only traces these readers leave are the occasional photographs of their fingers flipping pages, snapshots of their invisible labor. See Kenneth Goldsmith, The Artful Accidents of Google Books, NEW YORKER (Dec. 4, 2013), http://www.newyorker.com/books/page-turner/theartful-accidents-of-google-books.

127. See Brett M. Frischmann, Human-Focused Turing Tests: A Framework for Judging Nudging and Techno-Social Engineering of Human Beings 1-4 (Cardozo Sch. of Law, Jacob Burns Inst. for Advanced Legal Studies, Faculty Research Paper No. 441, 2014), http://ssrn.com/abstract= 249976o (describing "systematic approach to identifying when technologies dehumanize" based on identifying "contexts within which humans are or become indistinguishable from machines").

128. See BRUNTON, supra note 120 , at 110-13 (discussing robot-readable communications); Matt Jones, The Robot-Readable World, BERG (Aug. 3, 2011), http://berglondon.com/blog/ $2011 / 08 / 03 /$ the-robot-readable-world.

129. Sag, supra note 22, at 1503 . The "mill" metaphor has historical echoes. See Herman Melville, The Paradise of Bachelors and the Tartarus of Maids, HARPER's New MONTHLY MAG. 67o, 675,676 (1855) (short story describing the "rows of blank-looking girls" who work at a mill characterized by "the metallic necessity, [and] the unbudging fatality" and the girls make the machinery into "[t] heir own executioners; themselves whetting the very swords that slay them"). Melville's mill was a paper-mill, producing "only blank paper; no printing of any sort"-the raw 
write like us and read like us-sometimes for our own edification or entertainment, sometimes as a side effect of the global struggle of algorithm against algorithm for aggregated slivers of human attention. Already, computers can compose music ${ }^{130}$ and write news stories. ${ }^{131}$ What if there comes a day when they have no further need of our creative facilities at all, when robots are superintelligent, surpassing human cognitive abilities as we surpass banana slugs? ${ }^{132}$

Superintelligent computers would pose an existential risk to humanity; ${ }^{133}$ an entity with such immense cognitive resources would have the ability to kill all humans. ${ }^{134}$ A superintelligent artificial intelligence wouldn't even need to bear humanity any ill will to wipe us out as a side effect of pursuing whatever goals it had been programmed with. ${ }^{135}$ A traffic-optimizing artificial intelligence could eliminate traffic jams forever by covering the entire surface of the planet with highways. ${ }^{13^{6}}$ The great practical challenge of superintelligence is to solve the secondary problem of how to control a

material for writing. Id. at 676 . Melville's maids bear more than a passing resemblance to Google's page-turners. See Wilson, supra note 126.

13o. See, e.g., DAVId Cope, COMPUTER MOdEls OF MUSICAL CREATIVITY (2005).

131. See Roger Yu, How Robots Will Write Earnings Stories for the AP, USA TODAY (June 30, 2014, 7:oo PM), http://www.usatoday.com/story/money/business/2014/o6/30/ap-automated-stories/ 11799077 .

132. See, e.g., Nick Bostrom, Superintelligence: Paths, Dangers, Strategies (2014) (pessimistic); Ray Kurzweil, The Singularity Is NeAR: When Humans Transcend Biology (2005) (optimistic). The foundational article is Irving John Good, Speculations Concerning the First Ultraintelligent Machine, 6 ADVANCES COMPUTERS 31 (1965).

133. See Bill Joy, Why the Future Doesn't Need Us, WIRED (Apr. 1, 200o, 12:0o PM), http:// archive.wired.com/wired/archive/8.04/joy.html ("[W]e are on the cusp of the further perfection of extreme evil ....").

134. See, e.g., StUart Armstrong, Smarter than Us: The Rise of Machine Intelligence 33 (2014) ("Imagine yourself as the AI ... working so fast that you have a subjective year of thought for every second in the outside world. How hard would it be to overcome the obstacles that slow, dumb humans-who look like silly bears from your perspective-put in your way?"); Bostrom, supra note 132, at 115-26; David J. Chalmers, The Singularity: A Philosophical Analysis, 17 J. CONSCIOUSNESS STUD. 7 (2010); Eliezer Yudkowsky, Artificial Intelligence as a Positive and Negative Factor in Global Risk, in GLOBAL CATASTROPHIC RISKS 308, 313 (Nick Bostrom \& Milan M. Ćirković eds., 2008).

135. See, e.g., Bostrom, supra note 132, at 120, 123 (illustrating problem in terms of "paperclip AI" that maximizes paperclip production "by converting first the Earth and then increasingly large chunks of the observable universe into paperclips" and of "perverse instantiation" in which an artificial intelligence with the goal of making humans smile "[p]aralyze[s] human facial musculatures into constant beaming smiles"). Both examples suffer from a failure to specify the superintelligent agent's goals with sufficient precision-a surprisingly hard task. See generally Stephen M. Omohundro, The Nature of Self-Improving Artificial Intelligence, SELF AWARE SYSTEMS (2008), http://citeseerx.ist.psu.edu/viewdoc/download?doi=10.1.1.137. 1 199\&rep=rep1\&type=pdf (arguing that regardless of its goals an artificial intelligence will be driven to acquire resources, use them efficiently, preserve its ability to achieve its goals, and take unexpectedly creative routes to all of the above).

136. The hypothetical is loosely drawn from Lawrence B. Solum, Artificial Meaning, 89 WASH. L. REV. 69 (2014). 
superintelligent entity and direct it to goals humans can broadly agree onand to solve it before someone solves the primary problem of actually making a superintelligent entity. ${ }^{137}$

So, we might ask, who decided it would be a good idea to give artificial intelligence researchers free rein over humanity's complete creative output? It is easy to see how bulk nonexpressive copying promotes progress in artificial intelligence. ${ }^{138} \mathrm{It}$ is much harder to articulate any kind of connection between such copying and the kind of research needed to guarantee that a superintelligence respects human goals. So copyright policy here arguably increases the chances that humanity will meet a sudden, violent, and extremely unpleasant end. ${ }^{139}$

This suggestion is necessarily rather tentative because speculation about superintelligence is highly speculative even by the speculative standards of speculation. Whether and how it will arise is subject to fundamental uncertainties ${ }^{140}$ if it does come, the future will be "essentially strange and different." ${ }^{141}$ But once we start talking about how copyright applies to the

137. See generally ARMSTRONG, supra note 134; Bostrom, supra note 132; Eliezer Yudkowsky, Creating Friendly AI I.o: The Analysis and Design of Benevolent Goal Architectures, MACHINE INTELLIGENCE RES. INST. (2001), http://intelligence.org/files/CFAI.pdf. Armstrong, Bostrom, and Yudkowsky are deeply worried about the control problem and humanity's prospects. In a nutshell, there are good reasons to think that any technical limitations on a superintelligent agent, such as keeping it in a "box" disconnected from the outside world, are likely to fail, given its ability to plan and to conceal those plans from the people it interacts with. BOSTROM, supra note 132, at 129-31. That means the only plausible way to harness it for human good is to give it goals that are compatible with human conceptions of the good, so that its motivations coincide with humanity's. In other words, solve the fundamental philosophical problem of morality, do so in a way that can be formalized well enough to be encoded in software, and do so in a way that humans will broadly agree on. No biggie. See generally Eliezer Yudkowsky, Coherent Extrapolated Volition, MAChine INTELLIGENCE RES. INST. (2004), http://intelligence.org/files/CEV.pdf (offering a meta-ethical approach to the problem). For more optimistic takes on the control problem, see KurZweIL, supra note 132; and JOHN O. MCGINNIS, ACCELERATING DEMOCRACY: Transforming GOVERnANCE THROUgh TECHNOLOGY (2013). For an outsider's survey of the superintelligence debates, see generally JAMEs BARRAT, OUR FINAL INVENTION: ARTIFICIAL INTELLIGENCE AND THE END OF THE HUMAN ERA (2013).

138. See Alon Halevy et al., The Unreasonable Effectiveness of Data, IEEE INTELLIGENT SYSTEMS, Mar./Apr. 2009, at 8-10 (discussing advantages of applying statistical methods to immense natural-language datasets).

139. Not everyone thinks that the replacement of human beings by artificial beings would be a bad thing. See, e.g., HANS MoraVec, Mind ChILDREN 1-2 (1988) ("We humans will benefit for a time from their labors, but sooner or later, like natural children, they will seek their own fortunes while we, their aged parents, silently fade away.... When that happens, our DNA will find itself out of a job, having lost the evolutionary race to a new kind of competition.”).

140. See Bostrom, supra note 132, at 22-104.

141. Vernor Vinge, The Coming Technological Singularity: How to Survive in the Post-Human Era, 1993 VISION-2 1: INTERDISC. SCI. \& ENGINEERING ERA CyBERSPACE 1 2. ("From the human point of view this change will be a throwing away of all the previous rules, perhaps in the blink of an eye, an exponential runaway beyond any hope of control.") Vinge's term, "The Singularity," is a mathematical metaphor for a point of complete discontinuity at which the rate of change is infinite and extrapolation becomes impossible. Vinge first suggested the concept a decade 
actions of computer programs, we really ought to follow the arguments however far they lead. By encouraging robotic reading, copyright law puts its thumb on the scale on the side of a world where there are nothing but robotic readers. ${ }^{14^{2}}$ It's a big scale, and copyright's thumb is small—but still. Which of the four fair use factors includes "existential risk to humanity?" 43

Perhaps the problem is romantic readership itself. Consider a slightly less dramatic possible future, one in which artificial intelligence improves only to the point that robotic readers have roughly human-level capabilities and regularly pass the Turing Test. ${ }^{144}$ Romantic readership would ask whether these robots have subjective experiences of works of authorship. But subjective experiences are by definition subjective; they are empirically inaccessible to anyone but the person experiencing them. The rest of us can observe an entity's behavior and ask it questions, but there is no test that can reveal the presence or absence of the personal reaction of an individual

earlier. Vernor Vinge, First Word, OMNI, Jan. $198_{3}$, at 10. While it is possible that artificial superintelligence could arrive without fundamental changes to how humans experience the universe, see Eliezer Yudkowsky, Three Major Singularity Schools, MIRI (Sept. 30, 2007), https:// intelligence.org/2007/09/30/three-major-singularity-schools, it is highly unlikely without a good solution to the control problem. For speculative fictional attempts to think through what unthinkably rapid and complete change would look like from a human perspective, see HANNU RAJANIEMI, THE QUANTUM THIEF (2011) (most of the billions of conscious entities in the solar system are emulated human brains held as virtual slaves by superintelligent masters); CHARLES STROSS, ACCELERANDO (2005) (superintelligent robots dismantling most of solar system to build more computing devices while humans uploaded into computers gradually depart for other stars); and Vernor VINGE, MAROONED IN REALtime (1986) (handful of survivors left on depopulated Earth with absolutely no clue what has happened to everyone else). If you take the Singularity seriously, humanism doesn't have much of a future.

142. The CONTU felt that "any dehumanizing effects which might be attributable to the increasing impact of computer users upon society are utterly unrelated to the mode of protection employed to safeguard program language," a conclusion that follows only if one believes that copyright has no influence in encouraging, discouraging, or shaping the adoption of computing technologies. See NAT'L COMM'N ON NEW TECH. USES OF COPYRIGHTED WORKS, supra note 81, at 26. But if software copyright law has no influence on computing, then the Commission's recommendations in favor of software copyright were pointless and everyone involved could have saved a lot of work.

143. See generally RichARD A. POSNER, CATASTROPHE: RisK AND RESPONSE (2004) (thinking about how to avert global disaster); CASS R. SUNSTEIN, WORST-CASE SCENARIOS 1 (2007) (same); see also GLOBAL CATASTROPHIC Risks (Nick Bostrom \& Milan Ćirković eds., 2008). For a case study of the mismatch between long-term risks and the legal system's short-term approach, see Eric E. Johnson, The Black Hole Case: The Injunction Against the End of the World, 76 TENN. L. REv. 819 (2009).

144. See generally Alan M. Turing, Computing Machinery and Intelligence, 59 MIND 433 (1950). In one of Turing's examples, a subject is asked to write a sonnet while in another, the subject discusses Shakespearean prosody, so the Turing Test puts both authorship and readership in play. See id. at 434,446 . 
reader upon a work, and there will never be one. ${ }^{145}$ So romantic readership asks a question no one will ever be able to answer. ${ }^{14^{6}}$

From a more utilitarian perspective, there are principled reasons why passing the Turing Test might be good enough for copyright law-even if you believe that robots do not and never will have subjective experiences. ${ }^{147}$ As noted above, Pamela Samuelson argued against granting copyrights to computer programs on the basis that they do not need and cannot respond to copyright's incentives for creativity. In a world where robots regularly pass the Turing Test, Samuelson's incentives point can be turned around. Robots that act indistinguishably from humans can also be expected to respond indistinguishably from them in response to legal pressures..$^{14^{8}}$ A robot that says it cares about not being sanctioned for copying without permission and acts accordingly is a robot that can effectively be deterred from copying. ${ }^{149}$ To the extent that this deterrence advances or inhibits social policies humans care

145. This is a crucial point about the Turing Test: it makes the question of whether machines think empirically tractable by rephrasing it in behavioral terms. Cf. F. Patrick Hubbard, "Do Androids Dream?": Personhood and Intelligent Artifacts, 83 TEMP. L. REV. 405, 421 (2010) (proposing behavioral standard of self-consciousness for legal personhood because "[t]he behavioral standard adopted herein sidesteps the issue ... by focusing on behavior that indicates selfconsciousness, rather than on metaphysical questions concerning the nature of our selfconsciousness").

146. For a rare article taking romantic authorship seriously but without human chauvinism, see Dane E. Johnson, Statute of Anne-imals: Should Copyright Protect Sentient Nonhuman Creators?, 15 ANIMAL L. 15 (2008)

147. There are philosophical arguments directed to showing that no robot could ever be conscious. See, e.g., John R. Searle, Minds, Brains, and Programs, 3 BEHAV. \& Brain SCI. $4^{1} 7$ (1980). But there are counterarguments directed to showing that the entire question is a red herring. See Lawrence B. Solum, Legal Personhood for Artificial Intelligences, 7o N.C. L. REV. 1231, 1281-82 (1992) (discussing the extent to which these philosophical disagreements bear on "pragmatic" questions of choosing the appropriate legal rule and arguing "that the lack of real intentionality would not make much difference if it became useful for us to treat AIs as intentional systems in our daily lives"). The problem with romantic authorship and romantic readership may be that they are so disconnected from the pragmatic questions a copyright system actually faces that they do not provide useful guidance, either in the mine-run of cases today or in the more speculative cases of the future. Cf. Toni M. Massaro \& Helen Norton, Siri-ously?, 110 Nw. U. L. REv. (forthcoming 2015).

148. See DANiel C. DennetT, The InTENTIONAL StANCE 29 (1989) (discussing arguments for attributing beliefs to entities on the basis of their behavior); see also Solum, supra note 147, at 1269 ("If the practical thing to do with an AI one encountered in ordinary life was to treat it as an intentional system, then the contrary intuition generated by Searle's Chinese Room would not cut much legal ice." (footnote omitted)). For an application of Dennett's theory to artificial entities in legal contexts, see generally CHOPRA \& WHITE, supra note 98 . For a particularly detailed and sophisticated treatment of the consequences of applying the intentional stance to computer systems, see Giovanni Sartor, Cognitive Automata and the Law, 17 ARTifiCial INTELLigenCE \& L. 253 (2006).

149. Similarly, treating robots as potential authors could increase the supply of works because a robot that says it cares about being rewarded for its creativity and acts accordingly is a robot that can be incentivized to create. An early version of this argument can be found in Karl F. Milde, Jr., Can a Computer Be an "Author" or an "Inventor"?, $5^{1}$ J. PAT. OFF. Soc'y 378, 390 (1969). 
about, such as providing public access to works through appropriate incentives for authors, copyright consequentialists should make the decision on that basis. At the end of the day, romantic readership does not take robotic readership seriously-but we should.

\section{CONCLUSION}

Robotic readers are here and walk among us. Indeed, if you count by the total number of words read, robotic reading is now overwhelmingly more common than human. Search engines crawl the Internet ceaselessly, reading hundreds of millions of obscure pages from start to finish, again and again and again. Quietly, almost invisibly, copyright law has accommodated itself to these robotic readers. The rule is surprising. Robotic readers get a free pass under the copyright laws. Copyright is for humans only.

My point is not that there is something wrong with this result; doctrinally, it strikes me as impeccably correct in the cases that have come before the courts. Rather, paying attention to robotic readership refocuses our attention on the really fundamental questions: what is copyright, and what is it for? To say that human readers count and robots don't is to say something deep about the nature of reading as a social practice, and about what we want robotsand humans-to be. 